\title{
Images of the Feast in Antioch: Reflections about Dionysus' Mosaics in Domestic Settings
}

Immagini della festa ad Antiochia: Riflessioni sui mosaici di Dioniso in contesti domestici

\section{Gilvan Ventura da Silva}

\section{CpenEdition}

\section{Journals}

\section{Electronic version}

URL: https://journals.openedition.org/mythos/3364

DOI: $10.4000 /$ mythos.3364

ISSN: 2037-7746

\section{Publisher}

Salvatore Sciascia Editore

\section{Electronic reference}

Gilvan Ventura da Silva, "Images of the Feast in Antioch: Reflections about Dionysus' Mosaics in Domestic Settings", Mythos [Online], 15 | 2021, Online since 15 December 2021, connection on 15 December 2021. URL: http://journals.openedition.org/mythos/3364 ; DOI: https://doi.org/10.4000/ mythos.3364

This text was automatically generated on 15 December 2021.

Mythos 


\title{
Images of the Feast in
} Antioch: Reflections about Dionysus' Mosaics in Domestic Settings

\author{
Immagini della festa ad Antiochia: Riflessioni sui mosaici di Dioniso in contesti \\ domestici
}

Gilvan Ventura da Silva

1 The Syrian Antioch is considered one of the ancient world's megapoleis, both for its population size and its strategic role in the Greek East. ${ }^{1}$ Although Antioch already stood out as the Seleucid Empire's capital in the Hellenistic period, it went through a considerable development after the Roman conquest in 64 BCE. According to Uggeri, ${ }^{2}$ building on John Malalas' account, the renovation of the urban space was carried out by Caesar in $47 \mathrm{BCE}$, when the city would have received its impressive basilica (Kaisarion) and a theatre on the slope of Mount Silpius. Under Augustus, Antioch draws the Romans' attention, becoming a significant base for campaigns against the Parthians, as well as, later on, against the Persians. Antioch was also a warehouse for caravans from beyond the Tigris to the Mediterranean shore, which brought considerable wealth to its traders. The city was the focus of several trade routes linking Mesopotamia to the Mediterranean. Near Eastern merchants always had lodges and shelters outside its gates. ${ }^{3}$ Antioch was also a leading exporter of olive oil and wine from the Amuk Valley, enabling local aristocrats to amass a considerable wealth that entitled them to reach the senatorial order by the late first century $\mathrm{CE}{ }^{4}$

Beyond its political relevance and economic vitality under the Roman rule, Antioch was a vibrant cultural centre and a stage of many artistic, sports and religious events, such as its Olympic Games, held every four years, ${ }^{5}$ the Kalends, ${ }^{6}$ the Calliopea and Maiuma, ${ }^{7}$ not to mention the Christian and Jewish festivals. ${ }^{8}$ Antioch's people threw prodigiously lavish celebrations, and ancient writers widely recognised their festive ethos and fondness for singing, dancing and displays of cheerfulness both at public and domestic places as its distinctive trait. It was sometimes a focus of criticism, like in the Misopógon, in which the emperor Julian scolded the city not only for its profusion of dancers and 
flute players, but also because its inhabitants devoted many days and nights to sprees and orgies - which led, in his eyes, to a widespread propensity to insolence and disobedience. ${ }^{9}$ Julian targets an excessive clinging to tryphé, a word commonly associated with wickedness, as a form of lust, luxury and debauchery, as well as drunkenness and gluttony. ${ }^{10}$ Tryphé was considered a typical vice of dishonest, incompetent, voluptuous, or unintelligent people that were prone to indiscipline hence its frequent association with stásis.

3 Nonetheless, tryphé could also have a positive sense linked to joie de vivre, the joy of life: the attributes of people who can enjoy the best of life, such as pleasant weather, the bodily relaxation of bathing, the profusion of available goods as a sign of plenty and fortune, and the ties of friendship among fellow-citizens. ${ }^{11}$ Libanius, for example, considers it so in the Antiochikos, a panegyric for his hometown recited at the Olympic Games in 356. For the Antiochene sophist, the city stood out as a polis with a people full of tryphé, living together night and day in the streets, porticoes, and squares in good humour and happiness. ${ }^{12} \mathrm{He}$ even states that there would be no single place in the world where a festival is so intensively celebrated as Antioch, for every day, there was a feast. ${ }^{13}$

Fig. 1: Tryphé and Bios - Opus tessellatum - House of the Drunken Dionysus ( $3^{\text {rd }}$ century)

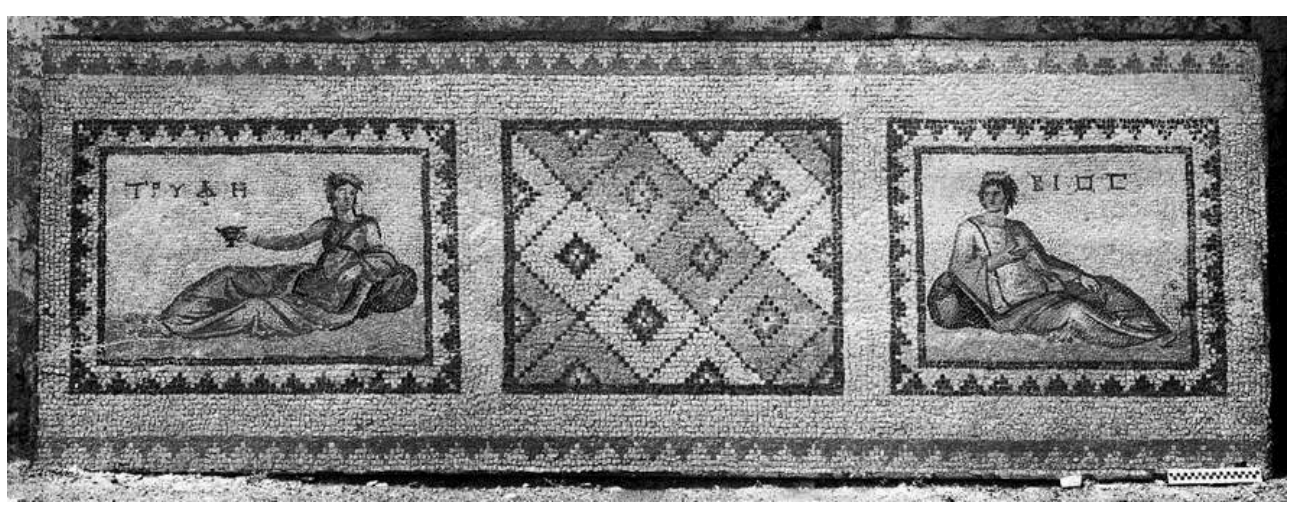

Reproduction authorised by The Department of Art \& Archaeology of Princeton University

4 The praise of tryphé in Antioch was not restricted to literary texts, since there are many floor mosaics with tryphé-allegories, ${ }^{14}$ like the corridor panel at the House of the Drunken Dionysus on Mount Staurin's slopes, towards Antioch's northeast. ${ }^{15}$ It depicts Tryphé as a woman reclined on a cushion (Fig. 1) dressed in a chiton with her legs covered by a mantle. She bears a wreath, and her right arm, adorned with bracelets, holds a receptacle with handles and a base, identified by Levi as a skyphos. ${ }^{16}$ The same set includes a male character, Bios, with a similar standing of Tryphé, to whom he directs his gaze. Bios' head is also adorned with flowers, he wears a long-sleeve tunic, and a mantle envelops his legs, extending to his left shoulder. Like Tryphé, Bios holds a cup in his right hand. Both images exemplify an artistic trend that emerged in the midthird century depicting personified ideals, virtues, and natural forces in mosaics with inscriptions turning the identification of the figures unequivocal. ${ }^{17}$ There are many examples of this trend, including mosaics with allegories of Apoulausis (enjoyment, entertainment), Soteria (salvation), Ananeosis (renewal), Dynamis (strength, power) or Epikosmesis (celebration). For Balty and Ling, such mosaics denote an intellectual concern since they seek to praise shared beliefs and values, either an ideal situation or 
a real one. ${ }^{18}$ The viewers stand before artworks pointing to a state of mind, a virtue or value - in this case, Tryphé, associated with the human condition, represented by Bios, converging in drinking at the symposion, the banquet. It is noteworthy that this panel is situated in a corridor that leads to a room decorated with another mosaic panel, in which an inebriated Dionysus is supported by a satyr (Fig. 2).

Fig. 2: Mosaic of the Drunken Dionysus - Opus tessellatum - House of the Drunken Dionysus $\left(2^{\text {nd }}\right.$ century)

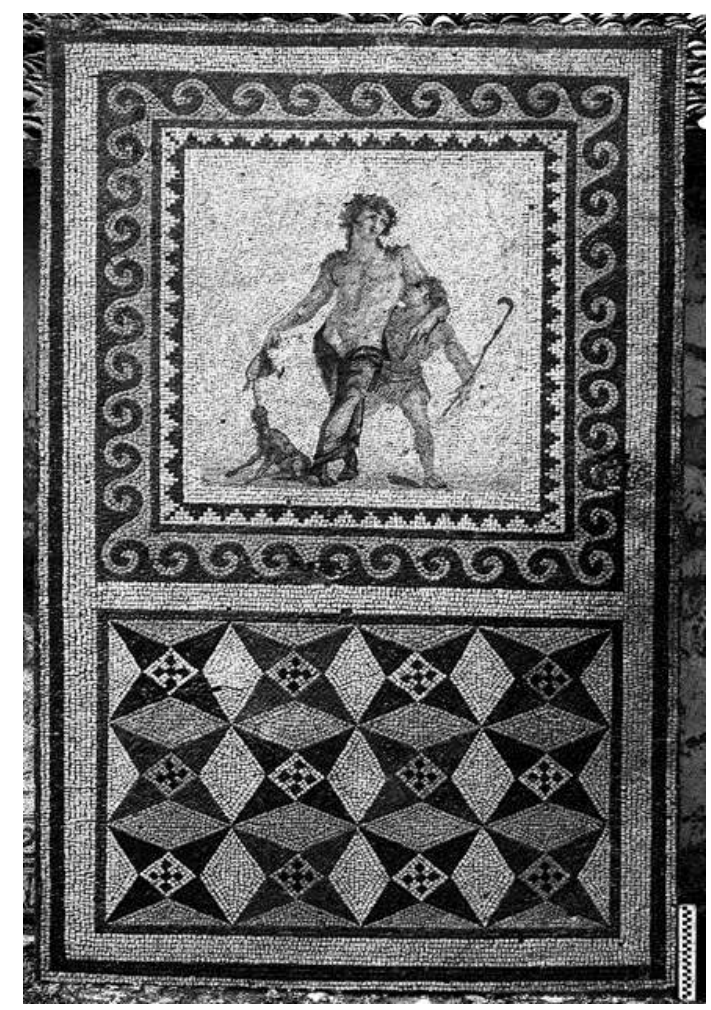

Reproduction authorised by The Department of Art \& Archaeology of Princeton University

This positive value of Tryphé in Antioch is remarkable and leads us to three readings. First, Tryphé seems to be a condition of human life, a virtue the human beings should cultivate to live well, which inspires its record on stone models to ensure its permanence. Second, as a festive rite in which participants meet to celebrate and socialise through wine consumption, the symposion links Tryphé to Bios. Finally, by the connection between Tryphé, Bios, the symposion and Dionysus, it is not by chance that both panels are part of a single architectural set, despite any chronological gap. ${ }^{19}$

6 Reflecting on Antioch's festive ethos depicted as a personified Tryphé raised to the status of Bios' companion, one can associate it with Dionysian scenes. The feast is an activity that creates a suspension of the usual time and space of daily life, its high emotional charge conferring it a memorable dimension not only towards the past, but also, and above all, the future, at least by the vows for its next edition. ${ }^{20}$ It is why the feast is one of the main entertainments and a powerful vector of social cohesion, mobilising and touching its participants. As Brandão argues, "together, differently united, we entreat from the festivity a proof that all this life, as well as our socially imposed life, is bearable and even good". ${ }^{21}$ The feast makes it possible to suspend one's routine obligations and constraints so that he or she may reach out to the Other and 
experience a catharsis, yielding a new meaning for life. By introducing the individual to a separate dimension from daily experience, the feast works in tune with the sacred or with the higher forces that sustain and transform those in contact with supernatural powers..$^{22}$ It could be seen in Antioch, with Dionysus as the chief patron of the local festivals.

We can assume that the popularity of Dionysus in Antioch was so intense, at least in the pagan milieu, that Libanius, in order to emphasise the festive ethos of the city, metaphorically declares that, if anyone mentions the name of Dionysus in Antioch, the god suddenly appears among mortals. ${ }^{23}$ Dionysus seems to have been one of the favoured deities in the city, drawing the attention of moralist writers who criticise, for example, the alleged presence of frenzied Bacchantes in the forum. ${ }^{24}$ There is evidence that even in the late Roman Empire, when the Christian movement was gaining strength under the leadership of figures like such as Meletius, John Chrysostom and Flavian, the popular devotion to Dionysus was still vigorous. It is not the case of Dionysus mysteria, held at distant places such as mountains and hills by few initiates, with no reliable evidence and still requiring further studies. Beyond such mysteria, there were inclusive and less secret kinds of worship publicly held when musicians and dancers, under the effect of wine in komoi and choroi, euphorically take the agora and other public places along with Bacchic revellers. ${ }^{25}$ However, there was a welldocumented and quite popular celebration in praise of Dionysus and Aphrodite, the Maiuma, held every three years at the urban centre and in Daphne's suburb (nearly eight kilometres to the South). As Belayche pointed out, even though the Maiuma in Roman times was not devoted to a specific deity but a celebration involving the use of water in various ways, as the etymological meaning of its name derived from the Hebrew mayin, "the waters", reveals, the festival was definitely dedicated to Dionysus and Aphrodite in Antioch. ${ }^{26}$

8 The Antiochian John Malalas emphasised such feature in the sixth century. In fact, he reports that after the restoration of the Olympic Games under Commodus, the emperor provided funds for horse racing held on Sundays and for Dionysus and Aphrodite's Maiuma, held every three years in Artemisium (May). ${ }^{27}$ It seems that Commodus provided a regular fund for the festival, for example, to implements as torches and lamps since it was a thirty-day nocturnal celebration. As a water festivity, the Antiochian Maiuma was probably held on the Orontes banks and at the Daphne Theater - a building well equipped for naumachiae. Its ritual program certainly included processions and pantomimes. ${ }^{28}$ The Maiuma is supposed to be active in the fourth century since John Chrysostom preached to the members of his congregation to prevent Christians from going to Daphne to attend the Maiuma orgies, as that place was about to be invaded by groups of dancers under the demoniac influence..$^{29}$ Thus, even in later times, the presence of Dionysus in Antioch was a fact that can explain Dionysiac motifs in mosaics up to the late fourth century. For that, and against those who see a process of "secularisation" in pagan festivals in Late Antiquity, Soler reaffirms those celebrations' sacred feature, which would have maintained their religious significance. 30

9 At this point, a question arises. Considering the links between the festivals and Dionysus, what is the evidence for the god's presence in Antioch? Unfortunately, the documentation is still scarce and inconsistent over time. The first clues appear in coins from the second century BCE, in which the god's effigy is associated with Seleucid 
rulers. ${ }^{31}$ As Malalas reports, Tiberius would have ordered the construction (or reconstruction) of a temple to Dionysus on a mountain and displayed two large statues of Amphion and Zethus, sons of Zeus and Antiope, in front of the building. ${ }^{32}$ Norris assumes this mountain is Mount Silpius, and the temple would have been built in the Epiphania quarter. ${ }^{33}$ Downey, in turn, argues that it was built on a podium with a staircase sided by the statues of Amphion and Zethus. ${ }^{34}$ Briefly put, the Hellenistic coins and the temple either built or rebuilt by Tiberius are the earliest evidence of Dionysus in Antioch to date. Such dearth prevents us from safely placing its presence in the city's social fabric, but one must not disregard that it seems that there was a temple of Dionysus in the asty in the vicinity of the urban theatre, the so-called Theatre of Dionysus. However, the most reliable evidence for the god's presence is the sculptures and mosaics brought to light during the Princeton University team's digs in 1932-1939. The lack of confidence in dating some pieces and divergent interpretations remains a severe difficulty to scholars. In Antioch and its environs, archaeologists have collected five fragments of statues ascribed to Dionysus. Only one is widely recognised as an image of the god, whereas the others may be equally identified as Hermes' depictions. ${ }^{35}$ The image on which there is consensus dates from the second century and comes from a swimming pool at the House of Menander in Daphne. It depicts the god semi-naked and reclined over a trunk decorated with grape leaves and clusters. His head, feet and hands have either been broken or removed. ${ }^{36}$

The evidence is more reliable when it comes to the floor mosaic collection, arguably the most prominent legacy of the archaeological excavation in the 1930s. It is not by chance that Antioch is sometimes called "the city of mosaics" - the subtitle of a monograph by Scott Redford. ${ }^{37}$ Even though scholars initially aimed to identify the significant civic monuments described by Libanius and John Malalas, the Princeton team soon brought to light an unexpected treasure: the domestic opera tessellata in Antioch and its surrounding areas, such as Daphne, Yakto and Seleucia Pieria. A total of three hundred artworks were found. Some were sent to different American and French museums; others were either taken to Antakya's Museum or remain in situ. The earliest mosaics date to the early second century and the later ones to the first half of the sixth century, when they suddenly disappear from the archaeological record - a fact linked to the earthquakes of 526 and 528 and the Persian invasion of 540 that almost destroyed the whole city in a calamitous sequence of events..$^{38}$ Most mosaics of this set were identified soon after their discovery by Charles Morey, whose The Mosaics of Antioch (1938) synthesises the main stages of mosaic art in Antioch. In 1947, Doro Levi published his two-volume magnum opus, Antioch Mosaic Pavements, describing the pieces and their sites. This mosaic collection is the largest one in the Near East. Mosaic art flourished in the city during the imperial era when the opus tessellatum was disseminated, replacing the much more expensive opus vermiculatum. ${ }^{39}$ Despite the influences of Roman techniques, which enriched the menu of geometric themes, Antioch's connoisseurs appreciated local artisans' work, who followed patterns inherited from the Hellenistic times. ${ }^{40}$

11 As Huskinson states, mosaics provide valuable information to the city's cultural life, and its study has increased in recent decades. ${ }^{41}$ Still, the use of mosaic art as a source of information about Antioch's daily life is restricted. Among many questions opened by the mosaics, a relevant one is the study of shared beliefs and religious sensibilities, especially on Dionysus, a god frequently pictured in these artworks. ${ }^{42}$ Dionysus and his usual entourage - Satyrs, Maenads, Pan, Eros and Silenus - were found on many 
mosaics at Antioch and environs, dating between the second and fourth centuries. ${ }^{43}$ The god is depicted on eight panels: four of them located in the urban centre, two in Daphne, and two in Seleucia Pieria. Seven of these panels belonged to elite households, whereas only one was found on a public building - an Orontes Island's bath known as "Bath D". To shed light on the festive aspects of Dionysus, we will focus on the mosaics in which the deity appeared in celebratory scenes of the second century when this kind of iconography is more abundant. It should not be assumed that the mosaics portraying Dionysus's images must be directly associated with any particular religious ritual. However, this iconography reveals, on the one hand, the popularity of the deity in the city, and, on the other, the belief of the guests gathered for the symposion in the god's benevolence towards the activities that took place in that festive occasion. In this case, the Dionysus' mosaics are inextricably connected to a way of life whose keystone was the paideia, the ancient elite education, expression of a cultural identity based on religious acts, feelings and ideas conveyed by mythological images and narratives, as Huskinson observes. ${ }^{44}$

Fig. 3: Mosaic of the Drinking Contest between Dionysus and Heracles - Opus tessellatum - Atrium House (second century CE)

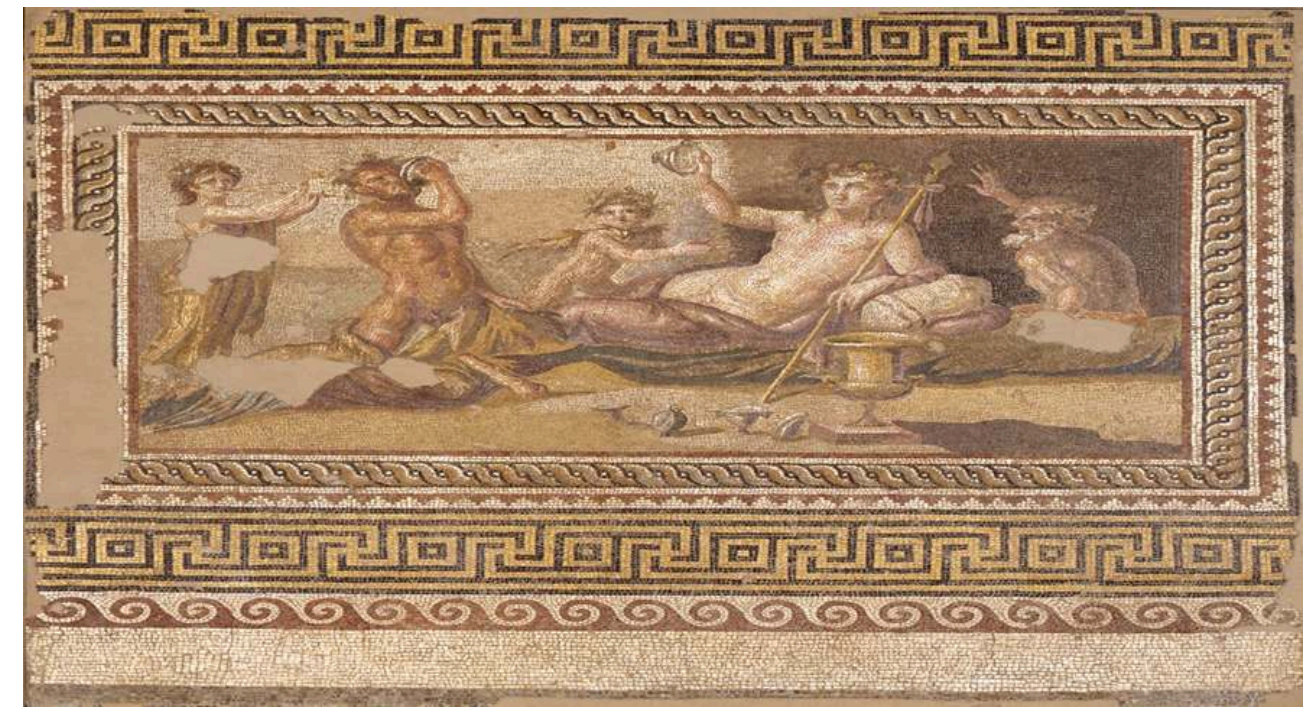

Reproduction authorised by Bridgeman Images USA

The first one is the Mosaic of the Drinking Contest between Dionysus and Heracles (Fig. 3) from the Atrium House - a large building located on the Orontes Island near the hippodrome, where the earliest mosaics were found. ${ }^{45}$ This mosaic, now at the Worcester Art Museum, was found at the entrance of a wide triclinium before a colonnade and a nymphaeum. ${ }^{46}$ The room also includes depictions of a satyr and a maenad, usual members of the Bacchic thiasos, and two other mosaics in the central area, the Mosaic of the Judgment of Paris and the Mosaic of Aphrodite and Adonis, the later in a very damaged state. The Mosaic of the Drinking Contest shows a symposion in which Dionysus and Heracles compete to decide who can drink more wine - a rather unusual theme in the visual repertoire and ancient literature. ${ }^{47}$ The only literary mention to Heracles meeting Dionysus in a symposion comes from the Dionysiaca, a long poem written in the mid-fifth century by Nonnus of Panopolis that mentions no contest between them. ${ }^{48}$ 

attendees. From left to right, the first is a young woman wearing a tunic and playing a diaulos. Next, a muscular and dark-skinned naked Heracles is on his knees, drinking a cup of wine while keeping his balance with his left hand on his thigh. His facial expression alludes to drunkenness. A long piece of cloth covers his legs on the floor, leaving only his right thigh exposed. His club rests on the cloth in front of him, in an oblique position. The third figure is a naked boy, dressed only in a mantle, with his hands stretched towards Dionysus, maybe pointing him as the winner. His identity is not sure: he may be either Eros - a usual member of Dionysus entourage - or Ampelos a youngster killed by a bull and transformed into the god's first bunch of grapes. Dionysus prominently appears in the centre, reclined on a long divan, with his left arm resting on a cushion. He is depicted with fair complexion and light skin, naked, but with his genitals and lower limbs covered by a cloth. Dionysus turns his cup - probably, a skyphos - with his right hand to show that it is empty. With his left hand, he holds his thyrsus decorated with laces and a pinecone on the top - one of his most usual attributes. The fifth and final character is Dionysus' preceptor Silenus, son of Hermes or Pan with a nymph, also half-naked. His right hand is raised as if proclaiming the contest's winner. On the ground, over a rectangular basis, stands a kratera and four scattered cups, perhaps indicating how much Dionysus and Heracles have drunk.

Wosaic of the Contest between Dionysus and Heracles was flanked by two other panels, now at the Baltimore Museum of Art, depicting a satyr and a maenad in a dance pose looking directly towards the other characters. A satyr is dressing in a petticoat and a nebris attached to his neck, falling over his shoulders on the left. ${ }^{49}$ His left-hand holds a Pan's flute, whereas his right hand is raised in a dance pose, with his legs crossed. The maenad is on the right side, wearing a blue chiton. Around her body, a brown mantle emphasises her movements. She plays the cymbals (cymbalistria), a percussion instrument used in the Dionysiac thiasoi. The presence of the satyr and maenad with musical instruments stress the festive ethos of the symposion, which takes place under the protection of the god. 
Fig. 4: Mosaic of the Drunken Dionysus - Opus tessellatum - House of Bacchic Thiasos ( ${ }^{\text {nd }}$ century)

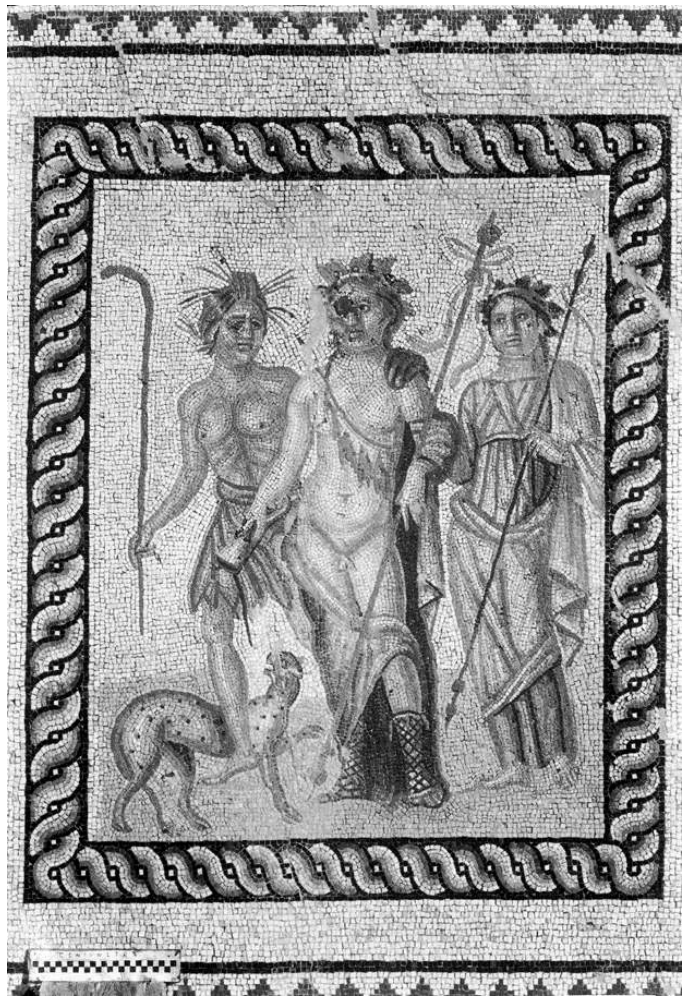

Reproduction authorised by The Department of Art \& Archaeology of Princeton University

15 The connection between celebrations with wine and Dionysus is also portrayed on another mosaic from the dining room of the House of Bacchic Thiasos, on the Mount Silpius' slopes (Fig. 4). Nowadays, this mosaic is part of the Museum of Antakya collection. It comprises three human figures and an animal one. Dionysus appears to be drunken in the centre, with ivy or grapevine leaves garland on his head. ${ }^{50} \mathrm{He}$ is naked, wearing only leather shoes, a long red mantle, and a ribbon with animal skin fringes on his chest. His right-hand holds a rhyton, and the left one holds a thyrsus decorated with laces and a pinecone. To his right, there is a satyr dressed in a petticoat, who brings small glass fillets in his hair, similar to small lightning bolts. In his right hand, the satyr bears a pedum - a club with a curved tip used by shepherds, one of the attributes of Pan, satyrs, and fauns. ${ }^{51}$ On the ground, between his legs, a panther seems willing to drink the wine drops that fall from Dionysus' cup. There is a maenad dressed in a long-sleeve chiton and a mantle covering her left shoulder and part of her legs on the left. She brings a garland of leaves, and her left hand holds a thyrsos similar to the one held by Dionysus. It is an outdoor scene, attested by the panther's presence, the inexistence of any architectural framing, the standing and moving characters, and by the ochre ground imitating the soil.

16 Another similar image comes from the above mentioned House of the Drunken Dionysus (Fig. 2). Again, it is a mosaic with two human figures and an animal one. Dionysus appears in a state of drunkenness in the centre, almost tripping on his legs. The half-naked deity has a garland of leaves on his head, a mantle covers his lower limbs, and wears red sandals. His right-hand holds a skyphos, whose content is poured into the mouth of a small panther, whereas his left-hand embraces the neck of the satyr who assists him. The satyr wears a petticoat, perhaps made of animal skin. His right 
hand supports Dionysus' inclined body, while his left hand holds a pedum. According to Doro Levi, the clean aspect of this image devoid of ornaments, and the unity expressed by the deity and the satyr suggest that this motif was borrowed from statuary. ${ }^{52}$ As well as in the Mosaic of the Bacchic Thiasos, this is an outdoor scene.

Fig. 5: Mosaic of the Triumph of Dionysus - Opus tessellatum - House of the Triumph of Dionysus ( $2^{\text {nd }}$ century)

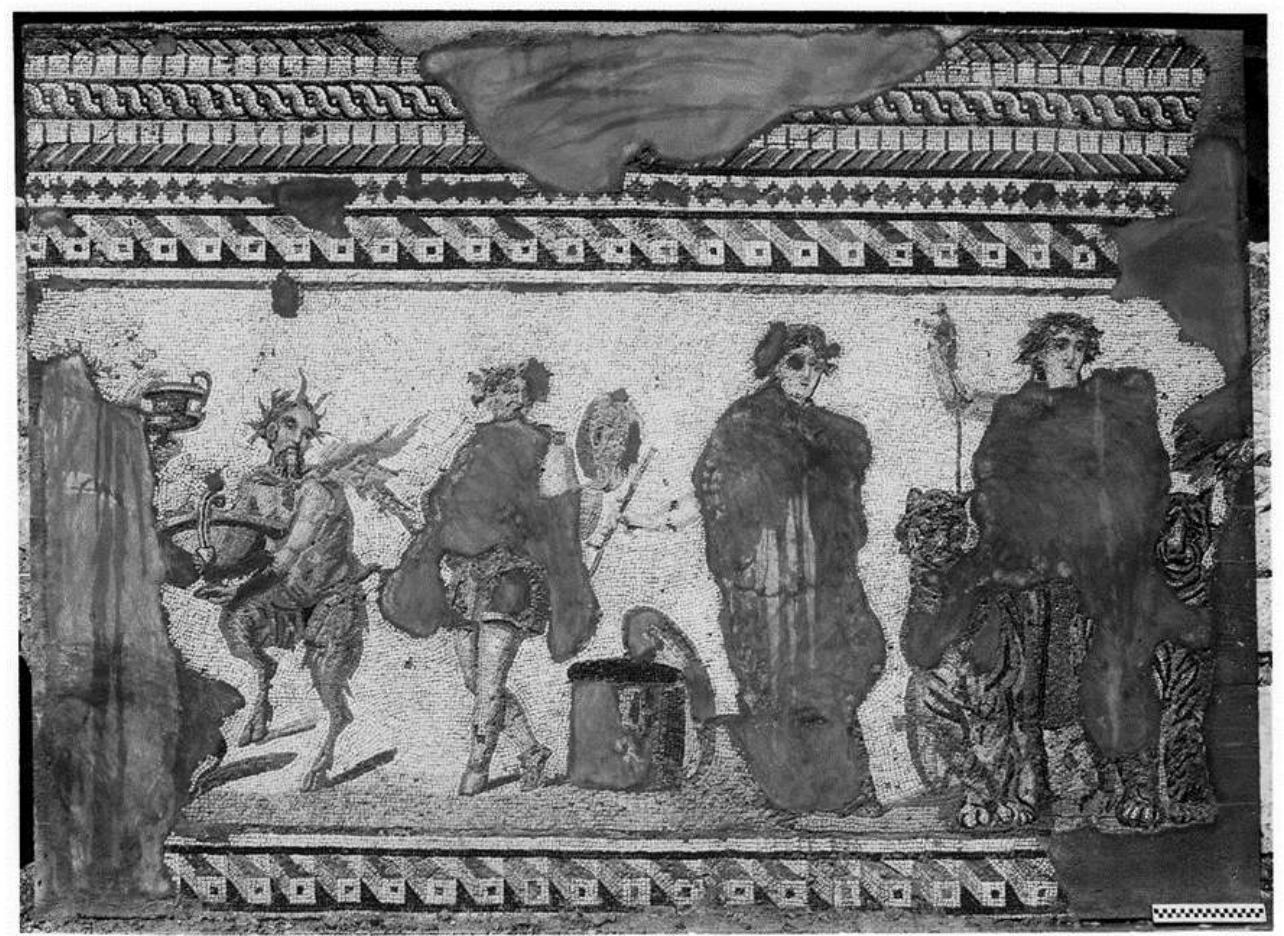

Reproduction authorised by The Department of Art \& Archaeology of Princeton University

The fourth and final mosaic in which Dionysus appears in a festive context comes from the House of the Triumph of Dionysus (Fig. 5) in Daphne, following the T-formation of the triclinium, the same shape of the House of the Atrium's mosaic. ${ }^{53}$ This room was preceded by columns separating the triclinium from a vast semi-circular pool, which ensures a privileged view to the dinner guests. ${ }^{54}$ Unfortunately, when the opus tessellatum covering the floor was found, its state of conservation was quite poor partly due to the use of glass tesserae, less resistant than stone. The best-preserved panel of this set, which stood at the basis of the T, is called Mosaic of the Triumph of Dionysus, now belonging to the Museum of Antakya. The central character of this composition, which lost its right side, is naturally Dionysus. He is frontally depicted, standing on a carriage pulled by tigers. The deity is crowned with a garland of leaves and flowers, holding the reins in his raised right hand. On his side, one partly sees the body of a maenad holding a club or sceptre in her right hand, with a garland on her head. On the ground, between the maenad and the figure to her side, there is a cista mystica, a cylindrical container with a lid that was used to carry sacred objects. In religious processions, the cista mystica would be closed. At the cista side, a maenad is dressed in a short chiton in a dance pose, shown by her crossed legs. Her head is adorned with a wreath, and her left hand holds a percussion instrument identified by Levi as a tympanum, while her righthand holds a torch with its higher part hidden under Pan's mantle. ${ }^{55}$ Pan has a wreath 
around his horns, and his hands hold a kantharos - a full wine cup with handles and a high base used in banquets and religious rites, particularly in Dionysiac ones. By his sight, he seems to be in a dense state of drunkenness. Lastly, on the panel's corner, the hands of a fifth figure, possibly a maenad, carry a krater.

The Mosaic of the Contest between Dionysus and Heracles and the Atrium House panels are the oldest known mosaic set. Other mosaics follow it, revealing an unequivocal association between Dionysus, wine, and festivities. It emphasises the playful aspect of the god, which quite well adjusted itself to Antioch's festive ethos. As Anghelina remarks, beyond the multiple facets of the deity, described in the Graeco-Roman literature as a "foreign god", a "saviour god" and even as the "madness god", Dionysus' most significant attribute, for which he had been recognised since time immemorial, is his status as inventor and patron of wine, an omnipresent beverage in ancient life, giving rise to one of the most important and long-lasting Greek celebrations: the symposion, when, gathered in a place surrounded by music and poetry, the participants rendered praise to the god and profusely consumed the beverage created by him. ${ }^{56} \mathrm{As}$ Rosenthal-Heginbottom points out, it was precisely the linkage between Dionysus and the symposion that turns his cult into one of the most long-lasting ones of the ancient world. ${ }^{57}$ At least until the rise of Islam, the Near Eastern mosaics with Dionysiac scenes also suggest it. In the same way, it also illuminates the emphasis given by late Christian writers to Dionysus and his cults. ${ }^{58}$

The symposion is usually represented in Greek literature as one of the most delightful situations, the moment when a man may enjoy life's pleasures and comfort his soul in the company of friends and relatives. ${ }^{59}$ This appreciation made it justifiable even to hold ceremonies in funerary contexts when people would seek to strengthen the affective bonds between the living and the dead. ${ }^{60}$ Wine consumption would also dissolve social conventions and nature-imposed limitations, at least for a brief interlude, so that individuals could be allowed to cross the boundaries between rational and irrational, human and divine, human and animal, reality and fiction, masculine and feminine, youth and old age, poverty and wealth. The act of drinking together would promote the union of individuals of different statuses and produce a confusion of roles in an experience that matches the sensation of happiness and freedom from daily life and social constraints. It is no coincidence that Dionysus was seen as the god able of bestowing eudaimonia and makariotes, pleasure and happiness, upon his devotees. ${ }^{61}$ The festivals are marked by inclusiveness, reinforcing the notion of koinonia since the god does not wish to be worshipped only by the initiates of his mysteries but by the entire polis gathered to dance in his honour. ${ }^{62}$

At this point, it is relevant to highlight the connection of Tryphé and Bios, impersonating collective aspirations and values, with the iconography of Dionysus, as we can see in the House of the Drunken Dionysus. As Saliou points out, Tryphé was considered an attribute of the polis, that is to say, of the population, being often associated, in the literary texts, with baths, love and consumption of exquisite food, essential things for enjoying a good life..$^{63}$ Inside the house, there was an older image of Dionysus circulating outside with his followers in an adjacent room. Viewed together, both panels seem to evoke, in a domestic setting, cultural ideals and practices shared by the inhabitants of the city. Such interpretation leads us to consider the public feature of the Greco-Roman houses. Although we usually see these buildings as private estates, they were places of intense socialisation and reproduction of social values in 
the Roman Empire. As Kondoleon points out, an elite house was more than a residential site. ${ }^{64}$ It was a place of economic, social, political, and religious practices denoting a continuous intersection between public and private life, including decorative elements that sought to reproduce the urban design inside the domus. In Antioch, both the Atrium House and the House of the Triumph of Dionysus have couches allowing diners to recline on divans to behold the domestic columns and nymphaea similar to what could be found in public spaces. ${ }^{65}$ The city was crossed from northeast to southeast by a Colonnaded Street, pointed towards the Orontes Island, and had a sumptuous nymphaeum as its focal point. This architectural complex was the highest object of pride, as seen from the praise to the colonnade and porticoes in the Antiochikos. ${ }^{66}$ Therefore, in Dobbins' opinion, ${ }^{67}$ the inner disposition of the houses in Antioch could be seen as a transposition of elements from urban to domestic architecture, which allows us to suppose a certain degree of porosity between streets and houses.

There is no reason for assuming the symposion as primarily a private ceremony, not usually belonging to both public and private spaces in Antioch. Two of our mosaics suggest that the symposion was often performed in open spaces: in the Mosaic of Drunken Dionysus and the Mosaic of Bacchic Thiasos, the deity appears inebriated, circulating outdoors with satyrs and maenads. These scenes seem to point out that Dionysus and his followers were not confined to private spaces. On the contrary, they reveal that a banquet, even if held within a house, could sometimes be continued outdoors by staging drunken komoi. ${ }^{68}$ Dionysus' interaction with the panther sipping wine drops falling from his cup can be interpreted as the already mentioned entanglement of human, divine and animal spheres produced by drunkenness. ${ }^{69}$ Describing the Kalends' festival, Libanius narrates the case of a feast that starts in a house and soon hits the streets. ${ }^{70}$ According to him, in the dawn of January 1st, after their banquets, diners would walk to taverns waking up their neighbours along the way. John Chrysostom describes a similar situation as he reports a wedding in which the guests, under the effect of wine, left the house in which the celebration was held to lead the bride around the city streets dancing to the sound of cymbals and flutes. ${ }^{71}$

This reading of Dionysius seeking to mobilise the city by revelry and collective wine consumption is reinforced by the Mosaic of the Triumph of Dionysus, in which the thiasos presents a spectacle to its viewers. The scene alludes to the god's triumphant return from India, where he was believed to have disseminated his worship by teaching locals to produce wine. Hence the mosaic strengthens the idea that Dionysus is a "foreign" god, one that arrives from elsewhere and erupts into the city with his rowdy retinue of satyrs and maenads. Detienne has thus interpreted Dionysus as an ambulant deity by definition, associated with continuous movement, music, and dance. ${ }^{72}$ The motif of a triumphant Dionysus returning from Asia on a carriage pulled by felines or centaurs, followed by his entourage, is not new and dates to the mid-fourth century BCE. ${ }^{73}$ Later on, this theme got considerable popularity, as this mythological scene became a prefiguration of Alexander's conquest of the oikoumene. Under the Roman rule, an increase can be observed in the number of mosaics with this theme. On the one hand, it was due to the dissemination of Dionysian themes in the Roman Empire itself. On the other, to the triumph iconography, a fairly common motif in the Roman Empire. Most currently known mosaics depicting a triumphant Dionysus come from Northern Africa, and date between the second and early fourth century. ${ }^{74}$ Nevertheless, the theme was equally appreciated by the Iberians, who used it until at least the fifth century ${ }^{75}$ In Antioch's case, the Mosaic of the Triumph of Dionysus suggests an open-air celebration 
around the god's adventus in the city with his entourage. Some key elements of this scene are the kantharos and the krater, which allude to wine consumption in public and collective ceremonies. These motifs point to an inclusive dimension, capable of inspiring the enjoy of feasting in the company of a god that expresses himself through epiphanies, inviting everyone to honour him in a joyful and carefree way.

To conclude, we would like to put forward a final thought about the dynamis of Dionysiac mosaics and their impact on the participants. The god's image in tesserae panels at Antioch's triclinia enables their reading not only as decorative but also opens the possibility of a religious sight, for they are material media capable of evoking the deity and interfering in attendees' behaviour. ${ }^{76}$ As Díez-Platas points out, in a pagan context the scenes on painted vases, carved in relief, sculpted in stone or created with tesserae sometimes acted as visible manifestations of the divine, opening a way of accessing a reality beyond the portrayed images, which in turn would find expression through them. ${ }^{77}$ Therefore, it can be argued that Dionysus' image in the mosaics is a kind of epiphany, a way of materialising the god in the place where human beings met to fraternise under the effect of wine, celebrating the joy of life.

Picturing Dionysus as a symposiast who consumes a drink of his own invention creates a link between the human and divine spheres within a feedback loop: the god's figure imitated the beholders' gesture who, on their turn, sought to follow him. Beyond their ability to act as occasional adornments, these mosaics acted as visual "access codes", capable of transporting the diners to another place under Dionysus' control. As JeanClaude Schmitt has argued, the image's role is less to represent an external reality than to build reality in a peculiar way, with an eminently active role. ${ }^{78}$ It leads us to consider what some authors define as the "agency of material culture" and "image-acts", referring to images' ability to interfere in human behaviour and elicit a wide range of emotions. ${ }^{79}$ It may be argued that the Antiochian Dionysiac mosaics were an invitation to joy and entertainment, both in the symposion and across the whole city. They are significant evidence that Antioch's festive ethos was not only a literary commonplace of authors engaged in the moral reformation of the polis in their criticisms of what they consider to be Antiochians excesses, such as the emperor Julian or John Chrysostom. On the contrary, it is more productive to interpret these mosaic's images as an anthropological feature of a people who, inspired by Dionysius and propelled by the consumption of wine, did not hesitate to celebrate as much as possible the delight of being in the world.

\section{BIBLIOGRAPHY}

ANGHELINA 2017: C. Anghelina, «The Drunken World of Dionysos», Trends in Classics 9 (2017), 113-161.

BALTY 2004: J. Balty, «Les mosaïques d'Antioche: style et rayonnement», Topoi. Orient-Occident 5 (2004), 257-269. 
BALTY 2000: J. Balty, «La culture d'Antioche à l'époque impériale: textes littéraires et mosaïques", in C. Nicolet, R. Ilbert and J. C. Depaule (eds.), Mégapoles méditerranéennes: géographie urbane retrospective, Paris 2000, 896-911.

BELAYCHE 2007: N. Belayche, « Des lieux pour le “profane” dans l'Empire tardo-antique? Les fêtes entre koinônia sociale et espaces de rivalités religieuses», Antiquité tardive 15 (2007), 35-46.

BELAYCHE 2004: N. Belayche, «Une panégyrie antiochéenne: le Maïouma», Topoi. Orient-Occident 5 (2004), 401-415.

BRANDÃo 1989: C. R. Brandão, A cultura na rua, Campinas 1989.

CAILLOIS 1988: R. Caillois, O homem e o sagrado, Lisboa 1988.

CAMPBELl 1988: S. Campbell, The Mosaics of Antioch, Toronto 1988.

Chuvin 1990: P. Chuvin, Chronique des derniers païens, Paris 1990.

СIMOK 2000: F. Cimok, Antioch Mosaics, Istanbul 2000.

CRIBIORE 2015: R. Cribiore, Between City and School: Selected Orations of Libanius, Liverpool 2015.

DALGIC 2015: O. Dalgic, «The Triumph of Dionysos in Constantinople: A Late Fifth-Century Mosaic in Context», Dumbarton Oaks Papers 69 (2015),15-47.

DAREMBERG, SAGLIO 1873-1919: C. Daremberg, E. Saglio, Dictionnaire des antiquités grecques et romaines, Paris 1873-1919.

DE GIORGI 2016: A. De Giorgi, Ancient Antioch: From the Seleucid Era to the Islamic Conquest, Cambridge 2016.

DETIENNE 1986: M. Detienne, Dionysos à ciel ouvert, Paris 1986.

DíEz-PlatAs 2013: F. Díez-Platas, «The Symposiast Dionysos: a God like Ourselves», in A. Bernabé et al. (ed), Redefining Dionysos, Berlin 2013, 504-525.

DoBbins 2000: J. J. Dobbins, «The Houses at Antioch», in C. Kondoleon (ed.), Antioch: The Lost Ancient City, Princeton 2000, 51-61.

DOWNEY 1961: G. Downey, A History of Antioch in Syria, Princeton 1961.

Downey 1941: G. Downey, «Ethical Themes in the Antioch Mosaics», Church History 10 (1941), 367-376.

DowNEY 1940: G. Downey, «Representations of Abstract Ideas in the Antioch Mosaics», Journal of the History of Ideas 1 (1940),112-113.

DunBaBIN 2003: K. M. D. Dunbabin, The Roman Banquet, Cambridge 2003.

DunBabin 1999: K. M. D. Dunbabin, Mosaics of the Greek and Roman World, Cambridge 1999.

DunBABiN 1971: K. M. Dunbabin, «The Triumph of Dionysos on Mosaics in North Africa», Papers of the British School at Rome 39 (1971), 52-65.

ELSNER 1996: J. Elsner, "Image and ritual: reflections on the religious appreciation of classical art", Classical Quarterly 46 (1996), 515-531.

FEHR 2003: B. Fehr, «What has Dionysos to Do with the Symposion?», Pallas 61 (2003), 23-37.

HAHN 2018: J. Hahn, «Metropolis, Emperors, and Games: The Secularization of the Antiochene Olympics in Late Antiquity», in S. P. Bergjan, S. Elm (eds.), Antioch II, Tübingen 2018, 53-71. 
HUSKINSON 2004: J. Huskinson, «Surveying the Scene: Antioch Mosaic Pavements as a Source of Historical Evidence", in I. Sandwell, J. Huskinson (ed.), Culture and Society in Later Roman Empire, Oxford 2004, 134-152.

JefFREYS, JeFFREYs, Scott 2017: E. Jeffreys, M. Jeffreys, R. Scott, The Chronicle of John Malalas, Leiden and Boston 2017.

KonDOLEON 2005: C. Kondoleon, «Mosaic of the Drinking Contest between Herakles and Dionysos", in I. Becker, C. Kondoleon (eds.), The Arts of Antioch, Worcester 2005, 178-181.

KonDOLEON 2000: C. Kondoleon, Antioch, the Lost Ancient City, Princeton 2000.

KonDOLEON 1995: C. Kondoleon, Domestic and Divine: Roman Mosaics in the House of Dionysos, Ithaca 1995.

LEEMANS et al. 2003: J. Leemans et al., 'Let Us Die That We May Live': Greek Homilies on Christian Martyrs from Asia Minor, Palestine, and Syria (c. AD 350-450), New York 2003.

LEVI 1947: D. Levi, Antioch Mosaic Pavements, v. 1, Princeton 1947.

Liebeschuetz 1972: J. H. W. G. Liebeschuetz, Antioch, City and Imperial Administration in the Later Roman Empire, Oxford 1972.

Lima 2000: A. C. C. Lima, Cultura popular em Atenas no V século a.C., Rio de Janeiro 2000.

LING 1998: R. Ling, Ancient Mosaics, Princeton 1998.

MARTIN 1959: R. Martin, «Commentaire archéologique de l'Antiochikos», in A. J. Festugière (ed.), Antioche païenne et chrétienne: Libanius, Chrysostome et les moines de Syrie, Paris 1959, 38-61.

MASSA 2014: F. Massa, Tra la vigna e la croce. Dioniso nei discorsi letterari e figurativi cristiani, Stuttgart 2014.

MENESES 2012: U. B. Meneses, «História e imagens: iconografia/iconologia e além», in C. F. S. Cardoso, R. Vainfas (eds.), Novos domínios da História, Rio de Janeiro 2012, 243-262.

MOREY 1938: C. R. Morey, The Mosaics of Antioch, London 1938.

MoRviLlez 2005a: E. Morvillez, « Klinai ou triclinium ? Sur la permanence de l'utilisation du mobilier grec de banquet à l'époque romaine », Mètis (2005), 57-76.

MoRviLlez 2005b: E. Morvillez, « Sed nudo latere et parvis frons aerea lectis. Sur les dimensions des tapis en $\mathrm{T}+\mathrm{U}$ et les types de lits employés ", in Actes du IXe colloque de l'Association Internationale pour l'Étude de la Mosaique Antique, Rome 2005, 1325-1334.

MoRviLlez 2004: E. Morvillez, «L'architecture domestique à Antioche dans l'Antiquité tardive: conservatisme ou modernitè », Topoi. Orient-Occident Supp. 5 (2004), 271-287.

Nicolet, ILBERT, DePaule 2000: C. Nicolet, R. Ilbert, J. C. Depaule (eds.), Mégapoles méditerranéennes: géographie urbaine retrospective, Paris 2000.

NoRMAN 2000: A. F. Norman, Antioch as a Centre of Hellenic Culture, Liverpool 2000.

NoRRIS 1990: F. Norris, «Antioch-on-the-Orontes as a Religious Center: Paganism before Constantine», Aufstieg und Niedergang der römischen Welt II, 18.4 (1990), 2322-2379.

PANOFSKY 2011: E. Panofsky, O significado das artes visuais, São Paulo 2011.

PellizzARI 2010: A. Pellizzari, «Terme e bagni pubblici e privati nella corrispondenza di Libanio», in C. Saliou (ed.), Les Sources de l'histoire du paysage urbain d'Antioche sur l'Oronte, Vincennes-SaintDenis 2010, 69-80. 
REDE 2012: M. Rede, «História e cultura material», in C. F. S. Cardoso, R. Vainfas (eds.), Novos domínios da História, Rio de Janeiro 2012, 133-150.

REDFORD 2014: S. Redford, Antioch on the Orontes: Early Explorations in the City of Mosaics, Istanbul 2014.

REMIJSEN, 2010: S. Remijsen, "The Introduction of the Antiochene Olympics: A Proposal for a New Date", Greek, Roman, and Byzantine Studies 50 (2010), 411-436.

Rosenthal-Heginbottom 2011, R. «Dionysos and his Retinue in the Art of the Late Roman and Byzantine Palestine», Actual Problems of Theory and History of Art: Collection of Articles 5 (2015), 188-194.

SALIOU 2016: C. Saliou, «Notes complémentaires», in Casevitz, M.; Lagacherie, P. (éd.). Libanios, discours XI, Antiochikos. Paris, 2016, 75-197.

SALIOU 2011: C. Saliou, «Jouir sans entraves? La notion de tryphé dans l'Éloge d'Antioche de Libanios», in O. Lagacherie, P. Malosse (eds.), Libanios, le premier humaniste, Alessandria 2011, 153-165.

SchMiTt 2007: J. C. Schmitt, O corpo das imagens, Bauru 2007.

SEAFORD 2006: R. Seaford, Dionysos, London 2006.

SILVA 2018: G. V. Silva, «Espaço, memória e festa no Império Romano: o festival das Calendas de Janeiro em Antioquia (séc. IV)», in G. V. Silva, E. C. M. Silva, Lima Neto, B. M. (org.), Usos do espaço no Mundo Antigo, Vitória 2018, 266-285.

SOLER 2010: E. Soler, «Sacralité et partage du temps et de l'espace festifs à Antioche au IVe siècle», in É. Rebillard and C. Sotinel (eds.), Les Frontières du profane dans l'Antiquité tardive, Paris 2010, 273-286.

SOLER 2006: E. Soler, Le Sacré et le salut à Antioche au IVe siècle après J.-C.: pratiques festives et comportements religieux dans le processus de christianisation de la cité, Beirut 2006.

SOLER 1997: E. Soler, «La Rue à Antioche au IVe siècle aprés J.-C.: entre 'kômoi' et 'pompai', les cortèges festifs comme reflect de la sociabilité», in A. Lémenorel (ed.), La rue, lieu de sociabilité?, Rouen 1997, 325-330.

TRABulsi 2004: J. A. D. Trabulsi, Dionisismo, poder e sociedade na Grécia até o fim da época clássica, Belo Horizonte 2004

UGGERI 2009: G. Uggeri, «Antiochia sull'Oronte. Profilo storico e urbanistico», in L. Padovese (ed.), Paolo di Tarso: Archeologia, storia, ricezione, Cantalupa 2009, 87-127.

VALERI 1979: V. Valeri, «Festa», in Enciclopedia Einaudi, VI, Turin 1979, 87-99.

YAMAÇ 2015: I. Yamaç, «The Dionysus Cult in Antioch», in P.M. Militello, H. Öniz (ed.), Proceedings of the $15^{\text {th }}$ Symposium on Mediterranean Archaeology, Oxford 2015, 677-683.

\section{NOTES}

1. On the concept of megapoleis applied to ancient cities, see NiCOLET-ILBERT-DePAULE 2000.

2. UGGERI $2009,95$.

3. LIEBESCHUETZ 1972, 77.

4. DE GIORGI 2016, 132. 
5. Like the Greek ones, Antioch's Olympic Games were held every four years. Under Claudius (41-54 CE), the gap between the Games changed to five years. The four-year pattern was resumed under Commodus (177-192 CE). The Olympic Games included not only athletic competitions, but communal banquets as well. In the fourth century, such banquets had experienced changes that attracted the criticism of some traditionalists, such as Libanius, who in his Oration 53, about the banquets held in Daphne on the occasion of the Olympic Games, disapproved of the invitation of young boys to the festival as he feared they could be seduced by older men. Additional information about Libanius' arguments against the Olympic banquets may be found in CRIBIORE 2015, 98-102. For a discussion of the evidence for the introduction of the Olympic Games in Antioch see REMIJSEN 2010. However, her conclusions about the subject are not undisputed: cf. HAHN 2018

6. The Kalends lasted four or five days, beginning on January $1^{\text {st }}$, with public and private celebrations. For further detail, see SILVA 2018.

7. Performed in praise of Calliope, one of Antioch's tutelary deities, the Calliopea were held every early summer with theatre performances and competitions at the hippodrome: cf. LIEBESCHUETZ 1972, 230. On the Maiuma, see BELAYCHE 2004, 410-414.

8. On Christian and Jewish celebrations in Antioch, see SOLER 2006.

9. Julian Mis. 8.

10. The polis tryphousa is a widespread theme in Greek literature, already mentioned, e.g., in Plato's Republic 2.372-373, where a city dominated by wine-drinking and eating excesses contrasted with a perfect city governed by temperance and moderation.

11. SALIOU 2011, 153-156.

12. For Libanius (Or. 11.255-257), Antioch was a city that never slept because of an efficient lighting system funded by its tradesmen, conferring safety to the people at night when even the central zones used to be dangerous. According to SALIOU 2016, 188, at least the baths should be open in Antioch after sunset. About the private and public baths in the Libanius' letters, see PELLIZZARI 2010. Regarding the lighting system of the city, see MARTIN 1959, 60.

13. Lib. Or. 11.266 .

14. See, e.g. PANOFSKY 2011, 51, on allegories.

15. The mosaics in Figures 1 and 2, dating to ca. 254-269, are part of the Antakya Museum's collection and come from the same house: CAMPBELL 1988, 64.

16. LEVI 1947, 224.

17. DOWNEY 1940.

18. LING 1998, 55; BALTY 2000, 901.

19. In the House of the Drunken Dionysus, the mosaic depicting the god was found in the socalled Room 5. On the basis of the material employed in the building, LEVI 1947, 40 dated the construction of the house after the earthquake of $115 \mathrm{CE}$. Later, during the third century, there was a restoration, when the panel containing the pictures of Tryphé and Bios was settled in a corridor (Room 6). In front of it, there was a courtyard separated by some limestone columns. Since both panels depict festive scenes involving the consumption of wine, and Rooms 5 e 6 are contiguous, one can assume that such rooms were regularly seen and occupied by the guests who attended the symposia held by the owners.

20. VALERI 1994.

21. BRANDÃo 1989, 9.

22. CAILloIs 1988, 97.

23. Lib., Or. 11.20. In this passage, Libanius' main purpose is surely to emphasize the abundance of wine produced by the farmers in the khora, whereas it is inserted in a praise of the agricultural resources of the city. However, it is worth noting the mention of Dionysus as a metonym for wine, which, in my opinion, strengthens the ties between the deity and the Antiochene festivals. 
Through the production and consumption of wine, the inhabitants could experience the presence of Dionysus in their daily life. According to NORMAN 2000, 11, n. 10, in his translation of the Antiochikos, the reference to Dionysus - along with Athena, the patroness of olive oil - is also an indication of the deity's favour towards the city. In his words, "these deities favour Antioch not only by their products but their presence in the temples erected in their honour".

24. On the Dionysian topos of later moralistic writers, not only acting on their contemporaries but also impregnating the interpretation of Dionysus and his cult in modern times, see esp. MASSA 2014.

25. The choroi were performed mainly in honour of Dionysus. Worshippers gathered around the thyméle - the Dionysiac altar - and sometimes even indulged in lascivious behaviour: SOLER 1997, 327-8. For the pompé of revellers who used to invade the agora at the Kalends, see SILVA 2018.

26. B ELAYCHE 2004, 410-414. As a celebration with water at its core and not restricted to a particular deity, the Maiuma naturally adjusted itself to the city's customs or region where it was held. For instance, in Ostia, it was performed in honour of Maia and Hermes.

27. Malalas, Chron. 12.3. Malalas refers to an old tradition about the performance held in May, a month dedicated to Artemis. However, SOLER 2006, 10 agreed with CHUVIN 1990, pointing to October as the most likely date based on Libanius' mention that Julian had suspended the funds to the festivities during his stay in Antioch between July 362 and March 363 (Lib. Or. 50.11). Nevertheless, Libanius does not openly state that the prohibited festival was the Maiuma, mentioning only a "repulsive festival" in Daphne. The question, therefore, remains open.

28. BeLAyChe 2004, 414.

29. Iohan. Chrysost. Hom. in Iul. 5.

30. SOLER 2010.

31. NORRIS 1990, 2348.

32. Malalas, Chron. 10.10.

33. See NORRIS 1990, 2348.

34. DOWNEY 1961, 180.

35. Cf. YAMAÇ 2015, 677. The author mentions a sixth fragment with a panther's head and part of a leg, supposedly an image of Dionysus accompanied by one of his favourite animals. Nevertheless, due to the scarcity of relevant evidence, we prefer not to consider it one of his images.

36. KONDOLEON 2000, 177.

37. REDFORD 2014.

38. HUSKINSON 2004, 138. See also DownEY 1961, ch. 18 and 19.

39. The opus vermiculatum (whose name derives from the Latin vermiculum, 'worm') is a mosaic composed of minuscule stone fragments, so tiny that only a closer look can distinguish the pieces. This technique was used whenever the artisans aimed to produce a painting-like effect. For DUNBABIN 1999, 25, the opus vermiculatum usually reproduced, in stone, scenes that were originally painted.

40. BALTY 2004, 264.

41. HuSKINSON 2004, 135.

42. KoNDOLEON 2000, 65.

43. On these figures, see DALGIC 2015, 30.

44. HUSKINSON 2004, 141. For a relevant discussion about the religious functions of ancient images, apart from their aesthetical nuances, see ELSNER 1996: although a great deal of ancient artworks conveys a religious meaning, sometimes this feature tends to be overlooked by the scholars of Classical art, who are most interested in issues like style and form, patronage and production, rather than in the religious importance of the ancient images, notably those that represent gods and heroes. Both approaches are not contradictory, as Elsner argues through his reading of texts 
from the Second Sophistic, in which there is, at the same time, a rhetorical celebration of ancient art from an aesthetic standpoint and a "prophetic, allegorical or talismanic flavour to the description of images".

45. These mosaics were produced after the earthquake of 115 , when this particular residence was probably rebuilt: DUNBABIN 1999, 160. The Atrium House was one of the first sites excavated at the beginning of the archaeological mission in 1932: see REDFORD 2014,40.

46. For a discussion of the already traditional identification of triclinia in Antiochean houses, see MORVILLEZ 2005a.

47. On the few images of the contest between Heracles and Dionysus, the 1930's diggings have found another depiction from the third century in a house at Seleucia Pieria, with the figures of the contestants and a maenad playing the cymbals: cf. СІмOK 2006, 135. Another mosaic with the same theme was recently found in Sepphoris, Galilee. The opus tessellatum covered the triclinium floor at the House of Dionysus: KonDOLEON 2005, 181.

48. Nonnus, Dyonisiaca 40.415-420.

49. A nebris was an animal skin (doe, panther, goat, she-goat, lynx, or fox) worn as apparel and symbol of a particular deity. It is detected in Artemis' worship, but a nebris was also used by Dionysus and his entourage (maenads, satyrs and sileni) to represent the living animal force evoked in the cult. See DAREMBERG-SAGLIO s.v. nebris, 4.40-41.

50. Dionysus' images usually included adornments such as grapevine and ivy leaves, especially in garlands on his forehead. The ivy has been interpreted as a symbol of immortality and victory over the winter since it can maintain its vigour all year round. It would also symbolise Dionysus' triumph over death. Moreover, ancient authors explain the association between ivy and the deity with the trance caused by its ingestion. Whatever the case may be, ivy, grapevine, and pinecone are Dionysus' main vegetal attributes; cf. ANGHELINA 2017, 116.

51. DAREMBERG-SAGLIO s.v. pedum, 4.368-369.

52. LEVI 1947, 40-41.

53. For a detailed discussion about the $\mathrm{T}+\mathrm{U}$ shape employed in Graeco-Roman dining rooms, see MORVILLEZ 2005b.

54. LEVI 1947, 91.

55. LEVI 1947, 93.

56. ANGHELINA 2017. See also DunBaBin 2003, 19.

57. ROSENTHAL-HEGINBOTTOM 2015, 188.

58. See, e.g., BELAYCHE 2007.

59. FEHR 2003, 25.

60. DUNBABIN 2003, 108.

61. TRABULSI 2004, 210.

62. See SEAFORD 2006, 28, and esp. BELAYCHE 2007, drawing attention to the expression of religious dissent in festivals.

63. SALIOU 2011, 156-157.

64. KONDOLEON 1995, 2. In his view, "unlike the nineteenth century bourgeois who withdrew from public life into his private drawing room, Romans commanded their domestic interiors as public stages, integrating commercial, social, and familial practices."

65. On the nymphaeum as a traditional architectural element in the houses of Antioch, see MORVILLEZ 2004, 273, 276.

66. Lib. Or. 11.213-218.

67. DoBBINS 2000, 60-61.

68. LIMA 2000, 36.

69. Alternatively, one could argue that the panther's figure, an untamed animal, sipping the wine drops from Dionysus' cup suggests the introduction of wilderness into a domestic environment. 
Both readings are plausible, and both stress the link between nature and culture established by Dionysus. On the manifold meanings of the figures inserted in the Antiochene mosaics, according to the observer's viewpoint, see DowNEY 1941.

70. Lib. Desc. 5.

71. Ioh. Chrysost. Hom.1Cor. 12.11 .

72. DetienNe 1986, 15.

73. A pebble mosaic from Olynthus (ravaged by Philip II's troops in 348 BCE) depicts the god on a car pulled by panthers followed by Eros, Pan and a cortege of maenads. It is the oldest known model of this type, although the theme of Dionysus riding a panther, which can be seen as a prefiguration of his triumph, was already portrayed on Attic vases from previous periods. See TRABULSI 2004, 123.

74. DunBabin 1971, 52.

75. The theme of Dionysus' triumph disappeared from North African mosaics in the early fourth century, but it seems that it was not wholly abandoned. In 1995 local workers in Samatya (Istanbul) found a large opus tessellatum depicting Dionysus' triumphant return surrounded by a thiasos of ecstatic devotees: see DALGIC 2015.

76. See, e.g., ELSNER 1996.

77. DíEz-Platas 2013, 505.

78. SснмітT 2007, 27.

79. For a discussion on the agency of material culture and images, see MENESES 2012 and REDE 2012.

\section{ABSTRACTS}

In the Roman Empire, Antioch, the metropolis of Syria Coele, stood out as a vibrant cultural centre and stage of many artistic, sports and religious events, including its own Olympic Games. The Kalends of January, the Calliopea and the Maiuma were special highlights, not to mention the Christian and Jewish festivals. Antioch was filled with celebrations. The key attribute of the Antiochean people was precisely its festive ethos and fondness for singing, dancing and displays of joy and cheerfulness, both in public and domestic sites. The city was considered to be under the direct influence of Dionysus, whose cult was one of the most ancient and noteworthy religious institutions in the city. This paper analyses some mosaics depicting Dionysus in domestic settings at Antioch and its environs, especially in its connection with the symposion.

Nell'Impero romano, Antiochia, la metropolis della Siria Coele, era un vivace centro culturale e teatro di molte manifestazioni artistiche, sportive e religiose, tra le quali le più celebri erano le Olimpiadi, le Calende di Gennaio, i Calliopea e la Maiuma, oltre alle festività cristiane e giudaiche. Antiochia era una città il cui calendario includeva una grande quantità di celebrazioni e la cui popolazione era nota proprio per il suo ethos festivo, ossia, per l'entusiasmo che dimostrava nel cantare e nel ballare, tanto nell'ambito pubblico quanto in quello domestico. Era considerata sotto l'influenza diretta di Dioniso, un dio il cui culto era uno dei più antichi e notevoli della città. L'obiettivo di questo articolo è di analizzare alcune rappresentazioni di Dioniso in mosaici collocati in contesti domestici ad Antiochia e nei suoi dintorni, e di considerare in particolare il legame di questo dio con la dimensione del simposio. 
INDEX

Keywords: Roman Empire, Antioch, Dionysus, mosaics

Parole chiave: Impero romano, Antiochia, Dioniso, mosaici

\author{
AUTHOR \\ GILVAN VENTURA DA SILVA \\ Universidade Federal do Espírito Santo, Av. Fernando Ferrari, n. 514, \\ Vitória, ES, \\ Brazil, \\ 29075-910, \\ gil-ventura(at)uol.com.br
}

